\title{
Cryptic dietary components of territorial damselfishes (Pomacentridae, Labroidei)
}

\author{
Shaun Wilson*, David R. Bellwood \\ Department of Marine Biology, James Cook University, Townsville, Queensland 4811, Australia
}

\begin{abstract}
The trophic status of 3 territorial damselfishes, Stegastes nigricans, Hemiglyphidodon plagiometopon and Dischistodus perspicillatus, was examined by comparing the resources available in territory epilithic algal communities (EACs) with gut contents. Samples were divided into epilithic algae and associated material in 3 size fractions: 10-125 $\mu \mathrm{m}, 125-500 \mu \mathrm{m}$ and $>500 \mu \mathrm{m}$. Each fraction was examined to determine its composition (detritus, sediment, algae, invertebrate), dry mass, organic matter content and $\mathrm{C}: \mathrm{N}$ ratio. The detritus-dominated 10-125 $\mu \mathrm{m}$ fractions were found to contain approximately half of the organic matter in territory samples $(46$ to $60 \%$ ) and had C:N ratios similar to the algal fractions. In all 3 species the $10-125 \mu \mathrm{m}$ fraction was ingested in proportion to its availability. In contrast, invertebrates, algae and sediment $(>500 \mu \mathrm{m})$ were under-represented in the diet. It is suggested that the detritus-dominated $10-125 \mu \mathrm{m}$ territory fraction is the primary source of organic material and nitrogen for all 3 species. Terntorality by damselfishes may be related to detrital production and accumulation rather than algal growth.
\end{abstract}

KEY WORDS: Detritus - Algae Feeding C:N ratio Trophic status

\section{INTRODUCTION}

Territorial damselfishes (family Pomacentridae) are a conspicuous part of shallow-water coral reef fish communities. Their defence of algal-covered territories, particularly against roving herbivores, has been well documented (e.g. Robertson et al. 1976, Montgomery 1980). Territorial pomacentrids appear to feed almost exclusively on the epilithic algal community (EAC) within their territories. These algae are usually more abundant and nutritious than non-defended algae (Brawley \& Adey 1977, Russ 1987). Furthermore, feeding observations, gut content analyses and assimilation studies have shown that algae are ingested and digested by these fishes (Lassuy 1980, 1984, Montgomery \& Gerking 1980, Polunin 1988, Galetto \& Bellwood 1994).

It is widely accepted that territorial pomacentrids are herbivores and that they actively 'farm' the algae within their territories (Horn 1989). 'Unsuitable' algae

·E-mail: shaun.wilson@jcu.edu.au are selectively removed, whilst the more 'suitable' algae are actively defended (Lassuy 1980). The basis for this selection of algae has been explained by either its nutritional quality, productivity or ease of digestion by acid lysis (Montgomery 1980, Lobel 1981, Russ 1987). In these studies, the focus has been on the epilithic algae as the sole food source. Other components of the diet have been largely overlooked.

EACs contain more for consumers than just algae. On coral reefs, sediment, detritus and invertebrates are an integral part of epilithic algal communities (Hatcher 1983, Zeller 1988, Russ \& St John 1989). In the present study this collection of material is referred to as the epilithic algal matrix (EAM), i.e. the EAC plus the non-living organic component (detritus), microbial component and inorganic material (sediment). Fish which feed upon these EAMs usually ingest a combination of resources (Lobel 1980, Kuo \& Shao 1991). It is, therefore, difficult to determine which components are targeted and which are nutritionally significant. Detritus, in particular, is a potentially important food resource in marine EAMs. 
Detritus sensu stricto has been described as non-liv. ing organic matter in various stages of decomposition (Gerking 1994), although a broader definition is used herein (defined in 'Sample analyses' section). Detritus s.s. can be subdivided into amorphic and morphic material. Amorphous material is usually very fine (0.5 to $250 \mu \mathrm{m})$, translucent, lacking discrete structure and of a high nutritional quality (Calow 1975, Bowen 1984, Alber \& Valiela 1994). In comparison, morphous detritus can be recognised as fragments of the organisms from which they originated. Morphous detritus is generally composed of large particles (250 to $2500 \mu \mathrm{m}$ ), high in structural carbohydrates and of relatively low nutritional value (Bowen 1984, D'Avanzo et al. 1991). Detritus has been reported to be a significant food source for many fish species, with evidence of selection for the finer detrital particles (Odum 1970, Bowen 1979, 1983, Mundahl \& Wissing 1987).

In this paper we reassess the trophic status of 3 torri. torial pomacentrids by examining the patterns of utilization of territorial resources, paying particular attention to algal and detrital components. All 3 species, Stegastos nigricans, Hemiglyphidodon plagiometopon and Dischistodus perspicillatus, have been classified as herbivores which farm the algal resources within their territories (Lassuy 1980, Lobel 1980, Horn 1989, Randall et al. 1990, Choat 1991). In the present study, the sediment composition and the quality and quantity of resources available in territory EAMs was compared with ingested material. This identified the most nutritious dietary components and the extent of selection for dietary components, organic material and sediment particle sizes. It provides the first quantitative assessment of the relative importance of detritus, invertebrates and epilithic algae in the diet of territorial pomacentrids on coral reefs.

\section{MATERIALS AND METHODS}

Behavioural observations and sample collections. This study was based on reefs around Lizard Island $\left(14^{\circ} 42^{\prime} \mathrm{S}, 145^{\circ} 30^{\prime} \mathrm{E}\right)$, in the northern section of the Great Barrier Reef. The study site extended along the lagoonal margin of the reef between Palfrey Is. and South Is. Here, Stegastes nigricans and Hemiglyphidodon plagiometopon defend territories amongst the open branches of Acropora spp. (A. nobilis, A. grandis and A. formosa) in 0.5 to $3 \mathrm{~m}$ of water, whilst Dischistodus perspicillatus defend territories over areas of adjacent open sand at 3 to $6 \mathrm{~m}$ depth.

The feeding behaviour of the 3 study species, Stegastes nigricans, Hemiglyphidodon plagiometopon and Dischistodus perspicillatus, was recorded on slates whilst using SCUBA. During 5 min observation periods the location of each bite (water column, sediment substratum, EAM) and the total number of bites were recorded. A total of 10 observations were undertaken on each species over a $10 \mathrm{~d}$ period (in March 1995), 5 in the morning (10:00 to $12: 00 \mathrm{~h}$ ) and 5 in the afternoon (14.00 to $17: 00$ h). Each fish was only observed once. The data were transformed $[\log (x+1)]$ to improve normality and homoscedasticity of the data prior to analyses using a 2-way ANOVA.

Seven individuals of each species were collected along with samples of the EAM in their territory. Fish were collected in the afternoon (14:00 to 16:00 h) using nets or spears and kept on ice during transport to the lab. To ensure that all material in the EAM was retained in Stegastes nigricans and Hemiglyphidodon plagiometopon territory samples, plastic click-seal bags were placed over the algal-covered coral branches before the branches were carefully broken with a chisel. Approximately $800 \mathrm{~g}$ of FAM-covered coral was removed from each territory. The bags were sealed and the entire contents returned to the lab for processing. The algae inside Dischistodus perspicillatus territories grows on and in the top few $\mathrm{mm}$ of the the sediment substratum, forming an algal-sediment mat. Portions of the mat were gently lifted from the substratum (approx. $400 \mathrm{~g}$ total) and placed in plastic click-seal bags which were sealed and returned to the lab for processing. Samples were taken from areas adjacent to $D$. perspicillatus feeding marks and were of a comparable depth to the feeding marks.

Sample processing. For each individual fish the territory samples were divided into 2 portions. A complete, undisturbed EAM sample was collected by cutting off the algae from coral branches from the first portion using scissors. This material was briefly washed on a $10 \mu \mathrm{m}$ filter with distilled water then frozen. The second portion was used to examine separate territory fractions. In this portion the algal-covered coral branches were brushed with a soft toothbrush and irrigated for approximately $2 \mathrm{~min}$ to remove epiphytic microalgae, detritus, sediment and invertebrates. This washed material along with the contents of the collection bag were then washed through 500, 125 and $10 \mu \mathrm{m}$ sieves using filtered sea water. The material in each sieve was briefly washed in distilled water to remove salt, placed in a plastic bag and frozen. The epilithic algae, which were now brushed clean, were clipped off the coral branches using scissors, washed with distilled water and frozen. In the brushed algal fraction and in all of the sieved fractions, any invertebrates visible under a dissecting microscope were removed. In Dischistodus perspicillatus territory samples, there was no algal fraction (almost all organic material passed through the $500 \mu \mathrm{m}$ sieve). 
The fish were measured ( $\mathrm{mm}$ standard length), weighed and dissected. The alimentary canal was removed intact, placed in a plastic bag and frozen. The material from the anterior half of the intestine was later removed for analyses.

Sample analyses. Visual analysis: Each of the territory samples (whole EAM, washed epilithic algae, and 3 sieved fractions) and a portion of the gut contents were examined visually using a dissecting microscope. Each sample was spread over a Petri dish, covering a $15 \times 15$ square grid placed underneath. For each of 50 randomly marked grid quadrats the dominant item (by area) was recorded, along with any other material present in the quadrat. These data were condensed into 4 categories: detritus, algae, sediment and invertebrates. The term detritus is used in the broad sense, i.e. to describe the organic material with no visible structure (at $\times 30$ magnification). In all samples this consisted primarily of amorphous, opaque, flocculent material. As live material could not be excluded, this material is not detritus sensu stricto (i.e. non-living organic material) as it may have contained microscopic algae, fungi and/ or bacteria. Values for each category are expressed as the percent of quadrats in which that category was dominant or present. The data were analysed using Vanderploeg \& Scavia's relativised electivity index (Vanderploeg \& Scavia 1979).

Organic content: The proportion of organic material in territory fractions was determined by bleaching $\mathrm{A}$ portion of each territory fraction and of the gut contents was placed into a glass vial, freeze-dried and weighed. The vials were filled with bleach $10 \%$ sodium hypochlorite), to at least twice the original sample volume. After 3 to $4 \mathrm{~d}$ the solution was decanted and replaced with fresh bleach. This was left for a further 3 to $4 \mathrm{~d}$, then rinsed 3 times with bleach and 5 times with filtered tap water, allowing $1 \mathrm{~h}$ for material to settle between rinses. The sediment which remained after bleaching was freeze-dried and weighed.

Normally, the difference in weights before and after bleaching is taken to represent the amount of organic matter present. However, as bleach breaks down organic material a layer of unknown composition forms on top of the sediment. These washings were retained during each rinse in preweighed filter paper A subsample of the washings was then dissolved in concentrated nitric acid, made up to volume with double-distilled water and analysed for calcium content using a Varian SpectrAA-10 atomic absorption spectrophotometer. The calcium concentration was used to calculate how much calcium carbonate was lost from each sample. These values were then used to adjust the estimated percentage organic matter. The total amount of organic material present in each territory fraction was calculated by multiplying the proportion of organic matter in each fraction by the proportion of total dry weight in that fraction. Standard errors (SE) were calculated using the equation:

$$
\mathrm{SE}_{a, b}{ }^{2}=\left(\operatorname{Mean}_{a}{ }^{2} \times \mathrm{SE}_{b}{ }^{2}\right)+\left(\operatorname{Mean}_{b}{ }^{2} \times \mathrm{SE}_{d}{ }^{2}\right)
$$

(after Bellwood 1995) where $a=\%$ of organic matter in the fraction and $b=$ proportion of total territory sample dry weight in the fraction. Because of non-independence, territory fractions for each species were compared using a Kruskal-Wallis single factor ANOVA by ranks, with significant differences examined using a Tukey-type multiple comparison test (Zar 1984).

A complete sample of the gut contents and an intact territory sample from the corresponding fish were also analysed to determine the total organic content (method as for fractions above). Total (\%) organic matter in the territory and gut samples of each species were compared using a 2-way ANOVA on arcsin transformed data (Zar 1984), followed by a Tukey test.

Carbon-nitrogen analysis: Samples were placed in acid-washed glass vials from which inorganic carbon in the form of $\mathrm{CaCO}_{3}$ was removed by adding excess hydrochloric acid. Each sample was then freeze-dried and homogenized using a glass mortar and pestle. Duplicate subsamples (1 to $10 \mathrm{mg}$ ) of each homogeneous sample were weighed into clean tin capsules and analysed for carbon, hydrogen and nitrogen content using a Carlo-Erba CHN analyser. Samples were reanalysed if duplicate values differed by $>10 \%$. Mean $\mathrm{C}: \mathrm{N}$ ratios (based on weight) for each fraction were compared using a Kruskal-Wallis single factor ANOVA by ranks for each species (Zar 1984). Analyses were restricted to the algal, 10-125 and 125-500 $\mu \mathrm{m}$ fractions.

To investigate the influence of large invertebrates on CN values, 2 complete portions of territory (with all components intact) were examined ( $\mathrm{n}=7$ for each species). In one, all invertebrates visible at $\times 30$ magnification were removed and in the other they remained undisturbed. C:N ratios were compared to examine the contribution of nitrogen from invertebrates. Data were analysed using a 2-way ANOVA, testing for the effect of invertebrates and fish species on C:N ratios. Data were $\log (x+1)$ transformed to improve normality and homoscedasticity prior to analysis using ANOVA.

Particle size distributions: Sediment which remained after bleaching the gut and teritory samples was passed through a sieve series $(500,250,125$ and $63 \mu \mathrm{m}$ ). Sediment in bleach washings (described above) was added to the $<63 \mu$ m category. Particle size selectivity was examined by comparing the sediment distributions in paired gut and territory samples. This was tested using Vanderploeg \& Scavia's (1979) relativised electivity index. Values were calculated for each fish separately ( 7 fish per species). 


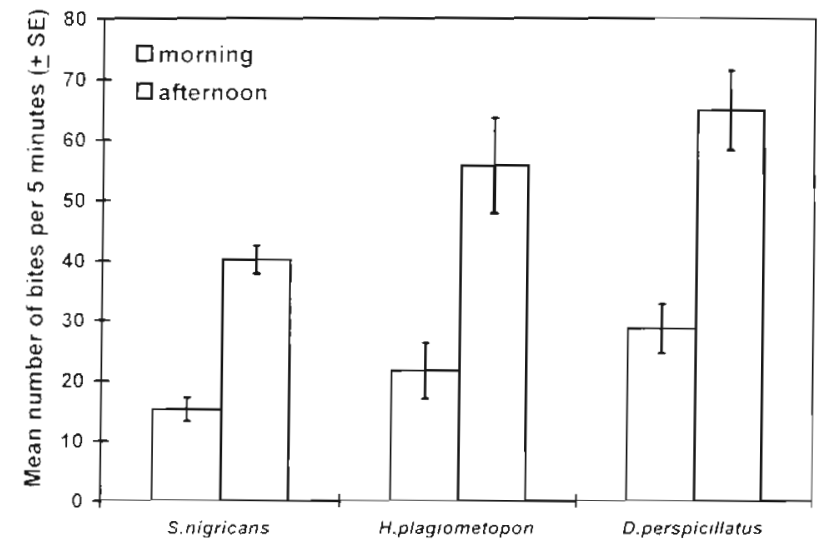

Fig. 1. Feeding rates of 3 territorial damselfish species during the morning $(10: 00$ to $12: 00 \mathrm{~h})$ and afternoon $(1: 4: 00$ to $1: 00 \mathrm{~h})$. For each time period $n=5$

\section{RESULTS}

\section{Feeding observations}

In all 3 damselfish species, feeding was generally confined to the areas defended. Stegastes nigricans and Hemiglyphidodon plagiometopon fed almost exclusively on the epilithic algal matrix which covers the branching Acropora spp. skeletons in their territories (Table 1). In $S$. nigricans, each bite removed a small clump of algae and associated material. H. plagiometopon, however, rarely removed any epilithic algae. Instead these fish appeared to mouth the algae on the upper side of coral branches, drawing off epiphytic material. Occasionally, algae were dislodged and spat out.

In contrast to Stegastes nigricans and Hemiglyphidodon plagiometopon, Dischistodus perspicillatus took almost all of its bites from the algal mat growing on and within the top few mm of the open sediment within its territory. Occasionally resident $D$. perspicillatus took bites from epilithic algal-covered rocks within or adjacent to their territories (Table 1).

In all 3 species, bite rates were higher in the afternoon than in the morning (Fig. 1, $F_{1.24}=88.89, \mathrm{p}<$ 0.001 ), with the same relative increase in feeding rates (i.e. no time of day $\times$ species interaction; $F_{2,24}=0.01$,

Table 1. Feeding locations of 3 territorial damselfishes (mean \% bites per location $\pm S E_{i} n=10$ for each species]

\begin{tabular}{|lccc|}
\hline & Epilithic algae & Sediment & Watercolumn \\
\hline Stegastes nigricans & $99.4 \pm 0.6$ & 0 & $0.6 \pm 0.6$ \\
Hemiglyhidodon plagiometopon & $97.0 \pm 3.0$ & 0 & $2.7 \pm 2.7$ \\
Dischistodus perspicillatus & $0.1 \pm 0.1$ & $99.9 \pm 0.1$ & 0 \\
\hline
\end{tabular}
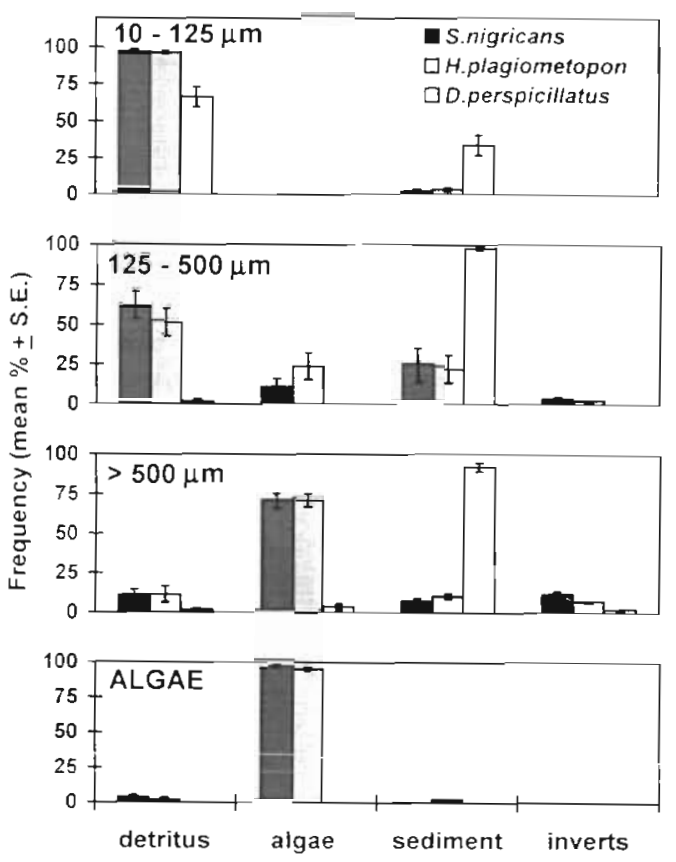

एig. 2. Composition of territory fractions in 3 damselfish species based on visual analyses. Vilues represent the mean percent of quadrats in which each of th: categories was the dominant component (50 quadrats per sample; SE based on 7 fish per species)

$p=0.994\}$. However, there was a significant difference between species $\left(F_{2,24}=13.5, p<0.001\right)$, with Stegastes nigricans taking fewer bites than either of the other 2 species (Tukey test: $S$. nigricans < Hemiglyphidodon plagiometopon $=$ Dischistodus perspicillatus) .

\section{Territory analysis}

Visual examination

In the 10-125 $\mu \mathrm{m}$ territory fraction, detritus was the dominant item in almost $100 \%$ of the quadrats from Stegastes nigricans and Hemiglyphidodon plagiometopon territories (Fig. 2). In Dischistodus perspicillatus approximately $85 \%$ of quadrats were dominated by sediment. However, in all 3 species, the bulk of the organic material in the 10-125 $\mu \mathrm{m}$ fraction was in the form of detritus.

The 2 coarse territory fractions $(125-500 \mu \mathrm{m}$ and $>500 \mu \mathrm{m})$ from Dischistodus perspicillatus territories were predominantly dominated by $\mathrm{CaCO}_{3}$ sediment, whilst Stegastes nigricans and Hemiglyphidodon plagiometopon quadrats were dominated by either algae and/or detritus. The 
algal fraction contained only small amounts of detritus in both $S$. nigricans and $H$. plagiometopon territories.

\section{Organic content}

Of the territory fractions, algae appeared to have the greatest percentage of organic matter, closely followed by the 10-125 $\mu \mathrm{m}$ fraction (Table 2). In Stegastes nigricans and Hemiglyphidodon plagiometopon territories, these 2 fractions were not found to be significantly different. In Dischistodus perspicillatus territories the fine fraction had a higher proportion of organic matter than the 2 coarse fractions.

From visual inspection of territories in the field, it appeared that epilithic algae were the dominant resource. However, if examined in terms of dry weight, epilithic algae represented on average only $18.8 \%$ of the total dry weight of the EAM in Stegastes nigricans territories. In Hemiglyphidodon plagiometopon territories the value was $11.1 \%$. In contrast, the $10-125 \mu \mathrm{m}$ fraction formed over $50 \%$ of the dry weight in both $S$. nigricans and $H$. plagiometopon territories (Table 3 ).

If these values are considered in relation to the percent organic matter in each fraction, the results are striking. Although the algal fraction contained a high percentage of organic matter, in terms of its contribution to the total ammount of organic material in the territory it represented only a relatively small component. For example, epilithic algae provided an average of $24 \%$ of the total organic material in Stegastes nigricans territories, compared to $60 \%$ for the $10-125 \mu \mathrm{m}$ fraction

Table 2. Organic matter content of each territory fraction for 3 damselfish species (mean \% of fraction dry weight $\pm \mathrm{SE} ; \mathrm{n}=7$ per species). Lines under values indicate fractions within a species which were not found to be significantly different ( $p<0.05$; Tukey test)

\begin{tabular}{|c|c|c|c|c|}
\hline & Algae & $\begin{array}{c}10-125 \\
\mu \mathrm{m}\end{array}$ & $\begin{array}{c}125-500 \\
\mu \mathrm{m}\end{array}$ & $\begin{array}{c}>500 \\
\mu \mathrm{m}\end{array}$ \\
\hline Stegastes nigricans & $66.1 \pm 3.1$ & $45.9 \pm 5.2$ & $29.8 \pm 5.5$ & $33.2 \pm 5.2$ \\
\hline Hemiglyhidodon plagiometopon & $55.5 \pm 4.1$ & $33.7 \pm 4.4$ & $26.6 \pm 1.7$ & $29.8 \pm 2.1$ \\
\hline Dischistodus perspicillatus & & $27.3 \pm 6.1$ & $\underline{3.6 \pm 1.4}$ & $2.9 \pm 0.6$ \\
\hline
\end{tabular}

Table 3. Epilithic algal matrix (EAM) composition in the territories of 3 damselfish species (mean \% of total territory EAM dry weight $\pm S E_{i} n=7$ per species)

\begin{tabular}{|c|c|c|c|c|}
\hline & Algae & $\begin{array}{c}10-125 \\
\mu \mathrm{m}\end{array}$ & $\begin{array}{c}125-500 \\
\mu \mathrm{m}\end{array}$ & $\begin{array}{l}>500 \\
\mu \mathrm{m}\end{array}$ \\
\hline Stegastes nugricans & $18.8 \pm 4.6$ & $60.6 \pm 3.5$ & $15.2 \pm 1.5$ & $7.4 \pm 0.9$ \\
\hline Hemiglyhidodon plagiometopon & $11.1 \pm 2.8$ & $54.6 \pm 7.4$ & $17.5 \pm 4.6$ & $16.8 \pm 3.6$ \\
\hline Dischistodus perspicillatus & & $9.4 \pm 1.0$ & $40.4 \pm 1.9$ & $50.2 \pm 1.6$ \\
\hline
\end{tabular}

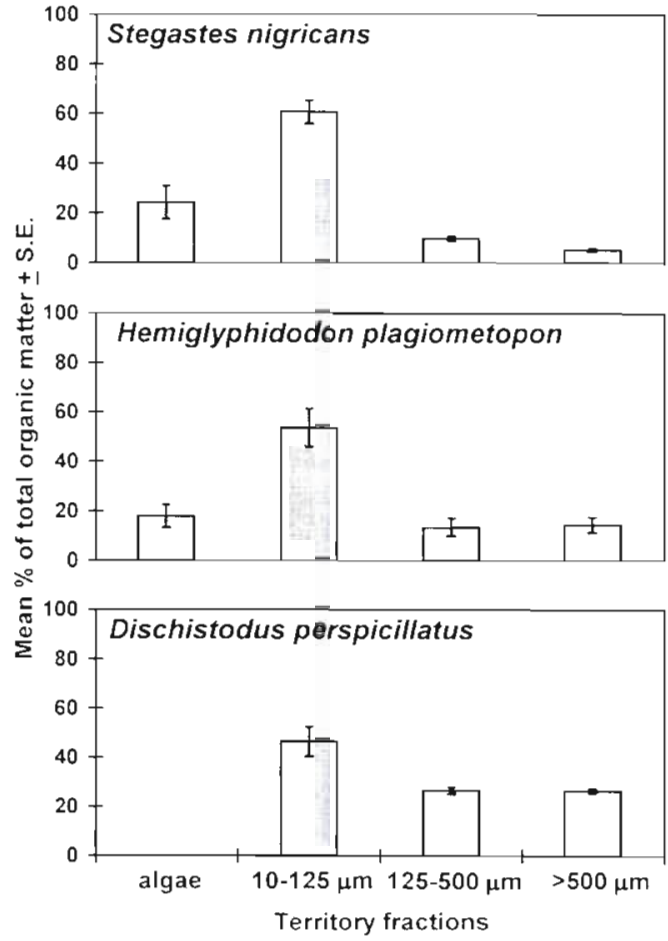

Fig. 3. Proportion of total territory organic matter in 4 territory fractions. For each species $n=7$

(Fig. 3). Hemiglyphidodon plagiometopon territories were similar, with $54 \%$ of the total organic matter in the $10-125 \mu \mathrm{m}$ fraction and only $18 \%$ in the algal fraction.

In Dischistodus perspicillatus territories the fine 10-125 $\mu \mathrm{m}$ fraction had the highest percentage of organic matter, yet this fraction represented only $10 \%$ of the total territory EAM dry weight (Table 3). Despite this low contribution to territory weight, the fine fraction on average still contained $46 \%$ of the total organic material. This was much greater than either of the 2 coarse fractions (Fig. 3). Thus, in all 3 species, the fine 10-125 $\mathrm{mm}$ detritusdominated fraction of the territory was the main source of organic material.

\section{Carbon:nitrogen ratios}

The ratios of organic carbon to nitrogen in all Stegastes nigricans and Hemiglyphidodon plagiometopon territory fractions were between 5:1 and $10: 1$, suggesting that both the algal and detrital material were of a high quality. The mean ratios of each fraction (Table 4) were not found to be 
significantly different (Kruskal-Wallis tests) in S. nigricans ( $\mathrm{H}_{2}=0.83, \mathrm{p}>0.5$ ) or $H$. plagiometopon $\left(\mathrm{H}_{2}=3.59, \mathrm{p}>\right.$ 0.1). Fractions from Dischistodus perspicillatus territories had higher $C: N$ ratios than the other 2 species (Table 4). Variation in C:N ratios was also greater in $D$. perspicillatus samples; however, this variation may be attributed to the low percentage of organic material in these fractions.

Within the territories of each species, macro-invertebrates accounted for only 1 to $2 \%$ of the total dry weight (Table 5). The territories of Stegastes nigricans had the greatest relative weight of invertebrates and Dischistodus perspicillatus the least, although the means were not found to differ significantly between species $\left(F_{2,12}=\right.$ 1.02, $p=0.39)$. Macro-invertebrates also appear to contribute little to the overall nitrogen content of territories (Tabie 5). Anaiyses oi the C:IN ratios in territory samples with and with out invertebrates revealed no significant difference between C:N ratios $\left(F_{1,36}=0.10, \mathrm{p}=0.76\right)$, nor was there a species $x$ invertebrate interaction $\left(F_{2,36}=0.30, p=0.74\right)$. How ever, there was a difference between the 3 fish species in terms of the territory C:N ratios $\left(F_{2}{ }_{36}=10.69, p<\right.$ 0.001 ), with a Tukey test revealing a higher $C: N$ ratio in $D$. perspicillatus territories. The organic material from S. nigricans and Hemiglyphidodon plagiometopon territories therefore, appears to have been of a higher quality than that from $D$. perspicillatus territories.

\section{Selectivity by fish}

Detritus, algae and invertebrates

Visual analyses of gut contents and territory samples revealed the extent of selectivity for dietary components in terms of the proportion of quadrats in which the components were the dominant item (Fig. 4). In Stegastes nigricans, the relative proportions of the major dietary components in the gut contents were comparable to their occurrence in territory samples. However, in Hemiglyphidodon plagiometopon the discrepancy between gut contents and territory samples was marked, with algae being strongly under-represented the gut contents were almost exclusively detritus. Dischistodus perspicillatus gut samples were dominated by sediment, although there was an increased representation of both algae and detritus. In all 3 spe-
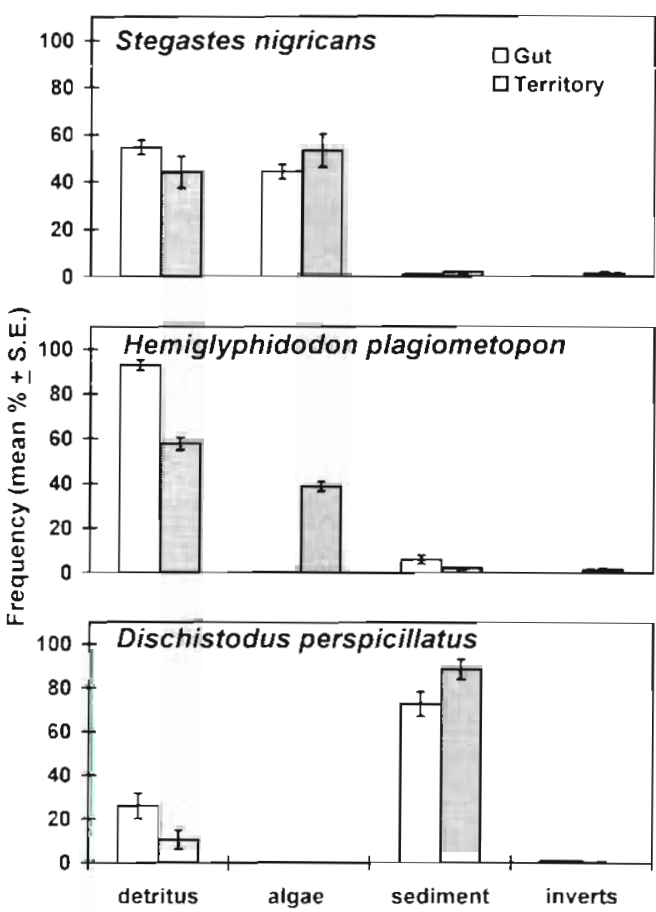

Fig. 4. Relative composition of territory samples and gut contents of 3 damselfish species, expressed as the mean proportion of quadrats in which each diet category was the dominant component (50 quadrats per sample; SE based on 7 fish per species)

cies, invertebrates made up an extremely small proportion of the ingested material. In $S$. nigricans and $H$. plagiometopon these invertebrates included polychaetes, crustaceans and foraminiferans. In D. perspicillatus foraminiferans were the only invertebrates recorded. 


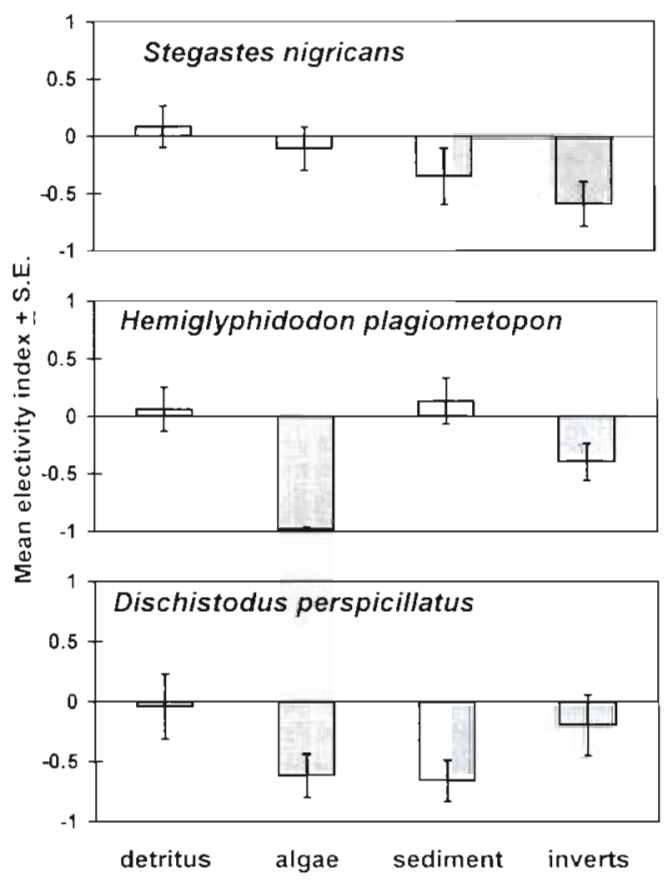

Fig. 5. Patterns of ingestion of territory dietary components in 3 damselfish species (mean Vanderploeg \& Scavia (1979) electivity indices $\pm S E_{\text {; }}$ data from Fig. 4 ]

Resource availability and ingestion patterns (Fig. 4) were compared using electivity indices (Fig. 5). In Stegastes nigricans the indices suggest that feeding was random with respect to detritus and algae, whilst sediment and invertebrates were under-represented (Fig. 5). Indices for Hemiglyphidodon plagiometopon also display a negative value for the invertebrate category; however, the most striking feature is the strong under-representation of algae. $H$. plagiometopon appears to have avoided ingesting algae. In Dischistodus perspicillatus algae and sediment also appear to be under-represented.

\section{Selection of organic matter}

The percentage of organic matter in the gut and territory of Stegastes nigricans were both approximately

Table 6 . Percentage of organic matter in whole territory samples and gut contents of 3 damselfish species (mean $\pm \mathrm{SE} ; \mathrm{n}=$ 7 per species)

\begin{tabular}{|lrc|}
\hline & Territory & Gut \\
\hline Stegastes nigricans & $53.5 \pm 6.5$ & $53.1 \pm 7.2$ \\
Hemiglyhidodon plagiometopon & $36.8 \pm 3.4$ & $34.7 \pm 4.4$ \\
Dischistodus perspicillatus & $3.9 \pm 0.7$ & $13.0 \pm 0.9$ \\
\hline
\end{tabular}

$53 \%$, compared to $35 \%$ in Hemiglyphidodon plagiometopon (Table 6). In marked contrast, Dischistodus perspicillatus territory samples contained only $3.9 \%$ organic matter, yet gut contents contained $13 \%$ organic matter (Table 6). Statistical analysis revealed no significant location (gut or territory) effect $\left(F_{1,36}=\right.$ $1.32, p>0.5)$ nor any species $x$ location interaction $\left\{F_{2,36}=2.45, p>0.2\right\}$. However, there was a species difference $\left(F_{2,36}=62.26, \mathrm{p}<0.001\right)$, with all 3 species differing in the organic content of the guts and territories (Tukey test $\mathrm{p}<0.05 ; D$. perspicillatus $<H$. plagiometopon $<$ S. nigricans).

\section{Sediment particle size selection}

In terms of dry weight, most sediment particles ingested by Stegastes nigricans were <63 $\mu \mathrm{m}$ (Fig. 6). The size distribution of sediment particles in Hemiglyphidodon plagiometopon guts was similar to $S$. nigricans, with the $<63 \mu \mathrm{m}$ fraction contributing most to the total sediment mass. Sediment in the territories of both species had a similar size distribution to those in the guts, with the exception of a greater proportion of particles $>500 \mu \mathrm{m}$ in $H$. plagiometopon territories. The particle size distribution in Dischistodus perspicillatus territories and guts was completely different to
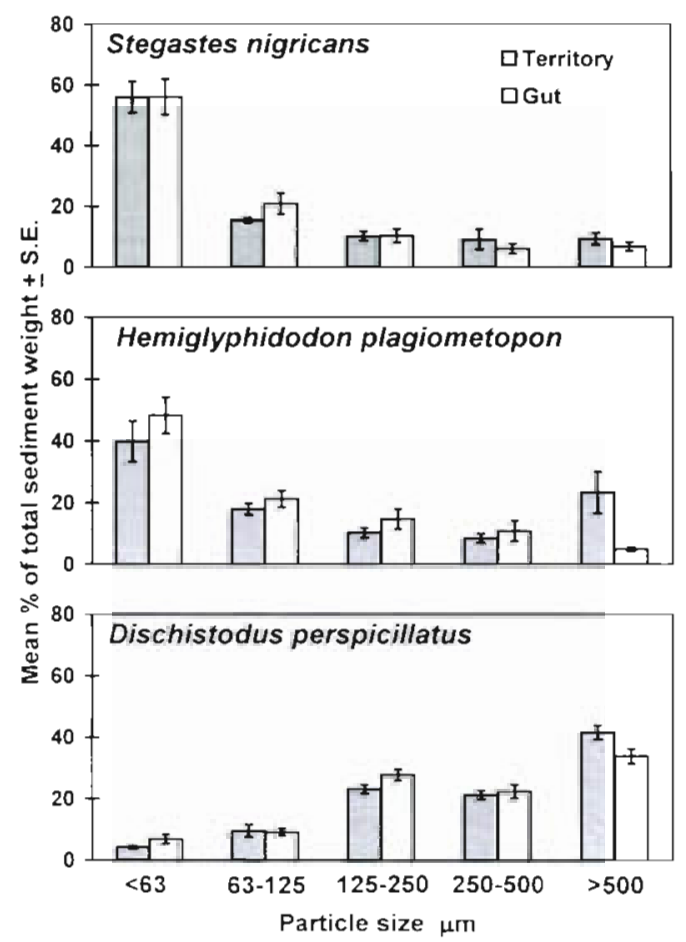

Fig. 6. Particle size distribution patterns from territory samples and gut contents of 3 damselfish species (for each species $n=7)$ 


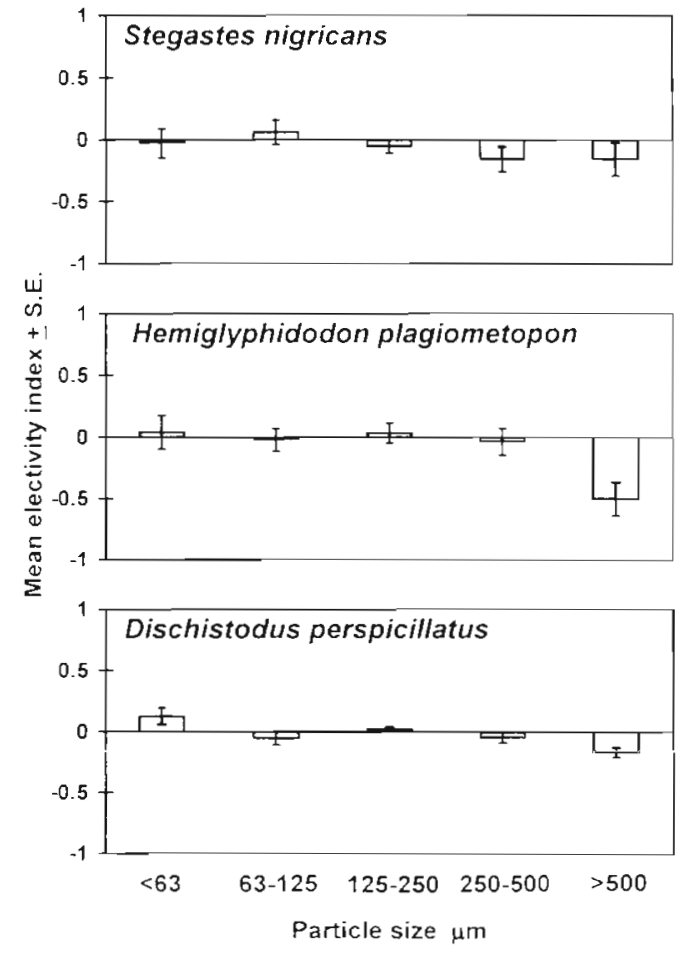

Fig. 7 Patterns of particle size ingestion in 3 damselfish species [mean Vanderploeg \& Scavia (1979) electivity indices \pm $S E_{i}$ data from Fig. 6]

the other 2 species. Most of the weight in these samples was provided by large particles (>125 $\mu \mathrm{m}$ ). The contribution of fine material to the territory and gut samples was relatively small (Fig. 6).

Electivity indices suggest that Stegastes nigricans and Hemiglyphidodon plagiometopon did not select the fine particles from their territory, although they may have avoided ingesting larger particles (Fig. 7). This was most evident in $H$. plagiometopon, which appeared to be feeding randomly on all particles less than $500 \mu \mathrm{m}$ and avoiding anything larger Dischistodus perspicillatus also displayed little selectivity, with only a weakly positive mean electivity index for particles $<63 \mu \mathrm{m}$ and a weakly negative value for particles $>500 \mu \mathrm{m}$.

\section{DISCUSSION}

The 3 damselfish species examined in this study represent some of the most conspicuously herbivorous fish species on the Great Barrier Reef. All 3 species actively defend territories containing a rich EAC on which they feed. It is widely suggested that it is the epilithic algae which are the focus of this type of territorial activity (Branch et al. 1992). Herbivorous fishes are vigorously excluded, undesirable algae are 'weeded out' and high standing stocks of algae are maintained (Robertson et al. 1976, Lassuy 1980, Russ 1987). Algae within territories may be highly productive and easily digested (Montgomery \& Gerking 1980), with territory EACs having a relatively high nitrogen content (Russ 1987). A large proportion of this productivity of territory EACs is consumed by the resident damselfish (Polunin 1988).

However, our data suggest that for all 3 study species, the epilithic algae were only a minor component of the diet and that the bulk of the organic matter and nitrogen was derived from other sources. Of these, detritus may have been a viable alternative to algae as the main nutritional resource. It appears that these 3 species may be predominantly detritivores, rather than herbivores.

\section{Feeding behaviour}

The observed feeding behaviour was consistent with previous observations on territorial pomacentrids, i.e. with most feeding within the territories (Lassuy 1980 , Lobol 1980, Montgomcry 1980, Polunin 1988) and higher feeding rates in the afternoon (Robertson 1984). Increased feeding in the afternoon has been recorded in a number of other 'herbivorous' reef fish species (e.g. Polunin \& Klumpp 1989, Bellwood 1995). It has been suggested that there is a direct relationship between feeding intensity and the concentration of photosynthate in the algae (Taborsky \& Limberger 1980, Polunin \& Klumpp 1989, Zoufal \& Taborsky 1991).

It is interesting to note that increased afternoon feeding rates have also been recorded in Ctenochaetus striatus, a territorial detritivorous acanthurid (Choat \& Bellwood 1985, Polunin \& Klumpp 1989, Purcell \& Bellwood 1993), and in scarids, which consume the complete EAM (Bruggemann et al. 1994, Bellwood 1995).

Why presumed herbivores and detritivores have the same feeding pattern is unclear Given that these patterns may not be related solely to changes in the epilithic algal component, the role of microalgae, detritus, microbes and other epiphytic material in this system needs to be investigated. It is noteworthy that studies of EAC quality throughout the day did not distinguish epilithic algae from other material and in algal quality analyses only macroinvertebrates and large epiphytes were removed (Zoufal \& Taborsky 1991) Furthermore, in Caribbean damselfishes, at least, diatoms appear to be a major constituent of damselfish territories (Robertson 1984). The role of detritus s.S., microbial populations and microalgae clearly needs to be determined.

As diurnal changes in the quantity and quality of detritus and epiphytic material have not been evalu- 
ated, the increase in afternoon feeding intensity by territorial pomacentrids should not be linked with epilithic algae alone. Indeed, at this point, a diurnal increase in the quality of detritus and epiphytic material appears to be as likely as an increase in epilithic algal quality.

\section{Analysis of food resources within territories}

Many studies have reported high standing stocks of algae within pomacentrid territories (e.g Brawley \& Adey 1977, Lassuy 1980, Montgomery 1980, Russ 1987). However, these studies are based on a comparison of algal biomass within and outside territories They do not indicate the importance of algae relative to other resources within the EAM

Quantitative assessment of organic matter in Stegastes nigricans and Hemiglyphidodon plagiometopon territories revealed that the algal fraction accounted for less than $25 \%$ of the organic material. The illusion of a territory dominated by epilithic algae was created by the volume of the algae in situ. However, as most algae are over $80 \%$ water (Levring et al. 1969), the dry weight contribution to the EAM may be relatively small. In contrast, the fine (detrital) fraction comprised over $50 \%$ of the organic material in S. nigricans and $H$. plagiometopon territories, and may have represented the primary nutritional resource for these species.

It must be noted that we examined only standing stocks of algae and detritus. Whilst it is suggested that pomacentrid territory EACs are highly productive (Montgomery 1980, Klumpp et al. 1987, Russ 1987), the rates of microbial and detrital production/accumulation are poorly known. To assess the relative importance of algal productivity in territories it must be compared to detrital production/accumulation rates. The source of the detritus also needs to be determined.

Unfortunately the accumulation rate of detritus in pomacentrid territories has not been measured. How ever, Koop \& Larkum (1987) estimated that detrital deposition at One Tree Reef, Australia, was between 1.5 and $4 \mathrm{~g} \mathrm{C} \mathrm{m}^{-2} \mathrm{~d}^{-1}$. In comparison, the rate of algal production in pomacentrid territories range from 1.2 to $2.6 \mathrm{~g} \mathrm{C} \mathrm{m}^{-2} \mathrm{~d}^{-1}$ [Russ 1987, Klumpp \& Polunin 1989). Given an estimated daily carbon uptake of the territorial pomacentrid Plectroglyphidodon lacrymatus of $1.43 \mathrm{~g} \mathrm{C} \mathrm{m}^{-2} \mathrm{~d}^{-1}$ (Polunin 1988), it appears that both detrital and algal production rates are of a comparable magnitude to that required to independently fulfil the carbon requirements of this species.

So far, we have considered only the quantity of organic material in territory fractions. What of the relative quality of algal versus detrital organic material? The size of the finest territory fraction $(10-125 \mu \mathrm{m})$ and its visual appearance suggests that this material was dominated by amorphic detritus. It would, therefore be expected to have been of a high nutritional value. The fine fraction of Stegastes nigricans and Hemiglyphidodon plagiometopon territories had mean $\mathrm{C}: \mathrm{N}$ values of 6.3:1 and 6.8:1 respectively (Table 4), which is comparable to previous estimates of amorphic detritus from macrophytes and algae (3:1 to 9:1; D'Avanzo et al 1991, Alber \& Valiela 1994).

Literature values for $\mathrm{C}: \mathrm{N}$ ratios of algae show a great deal of variation between species $(6.8: 1$ to $77.6: 1$; Atkinson \& Smith 1983). The algae in Stegastes nigricans and Hemiglyphidodon plagiometopon territories also had relatively low C:N ratios, 6.8:1 and 9.1:1 respectively (Table 4). Russell-Hunter (1970) calculated that only food with a $\mathrm{C}: \mathrm{N}$ ratio of $17: 1$ or lower could provide an adequate protein supply. As both the algal and detrital fractions from $S$. nigricans and $H$. plagiometopon territories were well below this value, both appear to represent high quality resources. It must be noted, however, that these estimates do not separate the small component of nitrogen in poorly assimilated non-protein compounds (cf. Horn \& Neighbours 1984). Nor is the relative value of specific nitrogen sources (essential amino acids etc.) considered.

If the fine fraction contained significant quantities of amorphic detritus, then this brings further potential benefits to the fish. Amorphous detritus contains limited refractory material (Bowen 1984) and is easily digested by fish (D'Avanzo et al. 1991). Detritus may also contain fewer secondary metabolites, which have been extensively linked to modifications of fish feeding (e.g. Paul et al. 1990, Hay 1991, Duffy \& Paul 1992).

Overall, the fine fraction of the Stegastes nigricans and Hemiglyphidodon plagiometopon territories was not only the major source of organic material, it was also of high quality, with a $\mathrm{C}: \mathrm{N}$ ratio comparable to that of epilithic algae. In Dischistodus perspicillatus territories, C:N ratios were relatively high; however, the fine fraction was still the major source of organic material and nitrogen. In terms of organic carbon and nitrogen, the most valuable dietary resource available to all 3 species appeared to be in the fine fraction, which probably contained both amorphic detritus and microscopic epiphytic material.

\section{The value of invertebrates}

The relatively dense growths of filamentous algale in pomacentrid territories contain a greater number and biomass of cryptofauna than in EACs outside territories (e.g. Lobel 1980, Zeller 1988). It has been hypothesised that these invertebrates supplement the fish's diet (Lobel 1980) 
In the present study, negative electivity indices (Fig 5) indicate that invertebrates were under-represented in the diet. This may not represent avoidance by the fish; the fish may simply be unable to locate or catch the invertebrates. However, the low number of invertebrates in the guts of all 3 species (Fig. 4) and the fact that the presence of cryptofauna did not significantly affect the C:N ratio of the territories (Fig. 5) suggest that invertebrates were unlikely to have provided a substantial source of organic nitrogen for the fish These results are consistent with the findings of Newton (1994), who suggested that invertebrates represent less than $0.3 \%$ of the nitrogen available in Stegastes nigricans territories.

\section{Territoriality and algal selectivity}

The 'weeding' or 'gardening' behaviour of many territorial pomacentrids suggests that they selectively modify the algal assemblages within their territories. The basis for this selection is assumed to be based on a preference for those algal taxa which are most productive and palatable (Lassuy 1980, Lobel 1980, Branch et al. 1992) However, in the present study, Hemiglyphidodon plagiometopon was found to actively avoid ingesting algae (Fig. 5). In addition, if territorial pomacentrids are obtaining the bulk of their nutritional requirements from detritus or other finefraction components, why would they remove certain algal species from their territories? These observations suggest that weeding may serve a purpose other than the removal of algae with low palatability or productivity.

It is possible that the high standing crop of algae within territories acts like a mop for trapping detritus. Furthermore many algal species produce mucus or slime (Clayton \& King 1990) which could facilitate the accumulation of particles from the water column. Differences in the external morphology of algal species would also alter the surface area available for trapping detritus. The territoriality and weeding by damselfishes may be directed to maintaining an EAC selected for its detrital production and/or trapping properties rather than for the growth or nutritional properties of the algae per se.

Current literature on algae from pomacentrid territories concentrates on the quantity and quality of the algae as a food resource. The possibility that algae perform a function other than nutrition has not been investigated, as previous studies have assumed that these fish are fully herbivorous. Future study of the efficiency of various algae to accumulate detritus may provide valuable information on the trophic status of territorial pomacentrids.

\section{Particle size selection}

In all 3 pomacentrid species, invertebrates, sediment and/or algae were under-represented in gut contents. Detritus, however, was consumed in proportion to its availability. As the finest territory fraction contained the highest proportion of organic material (Fig. 3), some particle size selection may be expected. Sediment particle size distributions in the guts were, therefore, examined for evidence of particle size selection. Overall, there was little evidence of such selection beyond an apparent avoidance of large particles,

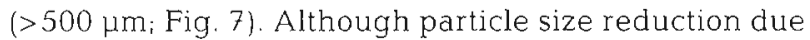
to pharyngeal processing is possible (cf. Bellwood 1996), avoidance of the larger $>500 \mu \mathrm{m}$ particles is also likely. Detrital particles in this size range are more likely to be morphic (Bowen 1984), and have a higher C:N ratio than the smaller particles (cf. Sinsabaugh \& Linkins 1990). Analysis of the organic content of the fraction greater than $500 \mu \mathrm{m}$ also revealed that large particles had a lower percentage of organic material. It would, therefore, be beneficial for fish to avoid this component of the territory if feeding on detritus. This was most evident in Dischistodus perspicillatus, where selection of fine particles and avoidance of large inorganic particles may be one of the methods used to increase the intake of organic material.

Previous studies on the mullet Mugil cephalus have demonstrated that these fish feed preferentially on high quality fine detrital particles, using the gill rakers and pharynx for selection (Odum 1970). However, the same species have been shown to feed preferentially on large particles when these are of a higher nutritional quality (Costantini \& Rossi 1995). Similarly, Bowen (1979) found that Tilapia mossambicus fed preferentially in the shallow waters of fresh water lakes, where the detritus had a higher concentration of protein. The primary decision, therefore, of what to select may be based on quality rather than particle size per se (see Hughes 1980).

There is presently no evidence that territorial pomacentrids posses any morphological traits which would improve selection of fine particles. However, if the initial decision for food selection is based on quality rather than size, it is possible that fish are using vision and/or olfaction, with associated behavioural modifications, to select food rather than rely on sized-based criteria.

The ingestion of detritus and particulate matter has been identified as a major feeding mode of marine invertebrates in both temperate and tropical systems (Hughes 1980, Hammond 1983, Alongi 1989). Furthermore, detritus has been recognised as a significant dietary component in a number of freshwater fish (Bowen 1983, 1984, Gerking 1994). In marine fish, how- 
ever, and on coral reefs in particular, detritivory or particulate feeding has been largely regarded as a feeding mode restricted to a few specialized taxa (cf. Odum 1970, Horn 1989, Purcell \& Bellwood 1993). The importance of fine detritus-dominated material in the diet of 3 territorial pomacentrids points to the need for a critical re-appraisal of the trophic status of reef fishes.

Acknowledgements. We thank: the staff of Lizard Island Research Station for field support; A. Hess for CHN analyses; $V$. Moltschaniwskyj and M. Hearndon for statistical advice; $\checkmark$. Hall for field assistance; G. Branch, J. H. Choat, K. D. Clements, M. Marnane, S. Purcell, D. R. Robertson, G. R. Russ and $O$. Bellwood for enlightening discussions and/or valuable comments. This work was supported by a Merit Research Grant from James Cook University. Part of this research was submitted by S.W. in partial fulfilment of an Honours degree in Marine Biology at J. C. U.

\section{LITERATURE CITED}

Alber M, Valiela I (1994) Biochemical composition of organic aggregates produced from marine macrophyte-derived dissolved organic matter. Limnol Oceanogr 39:717-723

A.longi DM (1989) Detritus in coral reef ecosystems: fluxes and fates. Diets, growth rates and secondary production of herbivorous coral reef fishes. Proc 6th Int Coral Reef Symp $1: 29-36$

Atkinson MJ, Snith SV (1983) C:N:P ratios of benthic marine plants. Limnol Oceanogr 28:568-574

Bellwood DR (1995) Direct estimate of bioerosion by two parrotfish species, Chlorurus gibbus and C. sordidus, on the Great Barrier Reef, Australia. Mar Biol 121:419-429

Bellwood DR (1996) Production and reworking of sediment by parrotfishes (family Scaridae) on the Great Barrier Reef, Australia. Mar Biol 125:795-800

Bowen SH (1979) A nutritional constraint in detritivory by fishes: the stunted population of Sarotherodon mossambicus in Lake Sibaya, South Africa. Ecol Monogr 49:17-31

Bowen SH (1983) Detritivory in neotropical fish communities. Environ Biol Fish 9:137-144

Bowen SH (1984) Evidence of a detritus food chain based on consumption of organic precipitates. Bull Mar Sci 35: $440-448$

Branch GM, Harris JM, Parkins C, Bustamante RH, Eekhout S (1992) Algal 'gardening' by grazers: a comparison of the ecological effects of territorial fish and limpets. In: John DM, Hawkins SJ, Price JH (eds) Plant-animal interactions in the marine benthos. Clarendon Press, Oxford, p 405-423

Brawley SH, Adey WH (1977) Territorial behaviour of threespot damselfish (Eupomacentrus planifrons) increases reef algal biomass and productivity. Environ Biol Fish 2:45-51

Bruggemann JH, van Oppen MJH, Breeman AM (1994) Foraging by the stoplight parrotfish Sparisoma viride. I. Food selection in different, socially determined habitats. Mar Ecol Prog Ser 106:41-55

Calow P (1975) On the nature and possible utility of epilithic detritus. Hydrobiologia 46:81-1.89

Choat JH (1991) The biology of herbivorous fishes on coral reefs. ln: Sale PF (ed) The ecology of fishes on coral reefs. Academic Press, San Diego, p 120-155

Choat JH, Bellwood DR (1985) Interactions amongst herbivorous fishes on a coral reef: influence of spatial variation. Mar Biol 89:221-234
Clayton MN, King RJ (1990) Biology of marine plants. Longman Chesire, Melbourne

Costantini ML, Rossi L (1995) Phosphorous transfer in systems of fish and amphipods exploiting detritus particles. Hydrobiologia 302:81-87

D'Avanzo C, Alber M, Valiela I (1991) Nitrogen assimilation from amorphous detritus by two coastal consumers. Estuar Coast Shelf Sci 33:203-209

Duffy JE, Paul VJ (1992) Prey nutrition quality and the effectiveness of chemical defenses against tropical reef fish. Oecologia 90:333-339

Galetto MJ, Bellwood DR (1994) Digestion of algae by Stegastes nigricans and Amphiprion akindynos (Pisces: Pomacentridael, with an evaluation of methods used in digestibility studies. J Fish Biol 44:415-428

Gerking SD (1994) Feeding ecology of fish. Academic Press, San Diego

Hammond LS (1983) Nutrition of deposit-feeding holothuroids and echinoids (Echinodermata) from a shallow reef lagoon, Discovery Bay, Jamaica. Mar Ecol Prog Ser 10:297-305

Hatcher BG (1983) The role of detritus in the metabolism and secondary production of coral reef ecosystems. In: Baker $\mathrm{JT}$ et al. (eds) Inaugral Great Barrier Reef conference. James Cook University, Townsville, p 317-325

Hay ME (1991) Fish-seaweed interactions on coral reefs: effects of herbivorous fishes and adaptations of their prey. In: Sale PF (ed) The ecology of fishes on coral reefs. Academic Press, San Diego, p 96-119

Horn MH (1989) Biology of marine herbivorous fishes. Oceanogr Mar Biol Annu Rev 27:67-272

Horn MH, Neighbours MA (1984) Protein and nitrogen assimilation as a factor in predicting the seasonal macroalgal diet of the monkeyface prickleback. Trans Am Fish Soc 113:388-396

Hughes RN (1980) Optimal foraging theory in the marine context. Oceanogr Mar Biol Annu Rev 18:423-481

Klumpp DW, McKinnon AD, Daniel P (1987) Damselfish territories: zones of high productivity on coral reefs. Mar Ecol Prog Ser 40:41-51

Klumpp DW, Polunin NVC (1989) Partitioning among grazers of food resources within damselfish territories on a coral reef. J Exp Mar Biol Ecol 125:145-169

Koop K, Larkum AWD (1987) Deposition of organic material in a coral reef lagoon. One Tree Island, Great Barrier Reef. Estuar Coast Shelf Sci 25:1-9

Kuo SR, Shao KT (1991) Feeding habits of damselfish (Pomacentridae) from the southern part of Taiwan. J Fish Soc Taiwan 18:165-176

Lassuy DR (1980) Effects of farming behaviour by Eupomacentrus lividus and Hemiglyphidodon plagiometopon on algal community structure. Bull Mar Sci 30:304-312

Lassuy DR (1984) Diet intestinal morphology, and nitrogen assimilation morphology in the damselfish, Stegastes lividus in Guam. Environ Biol Fish 10:183-193

Levring T, Hoppe HA, Schmid OJ (1969) Marine algae. Cram, De Gruyther \& Co, Hamburg

Lobel PS (1980) Herbivory by damselfishes and their role in coral reef community ecology. Bull Mar Sci 30:273-289

Lobel PS (1981) Trophic biology of herbivorous reef fish: alimentary $\mathrm{pH}$ and digestive capabilities. J Fish Biol 19: 365-397

Montgomery WL (1980) Comparative feeding ecology of two herbivorous damselfishes (Pomacentridae: Teleostei) from the gulf of California, Mexico. J Exp Mar Biol Ecol 47:9-24

Montgomery WL, Gerking SD (1980) Marine macroalgae as food for fishes: an evaluation of potential food quality. Environ Biol Fish 5:143-153 
Mundahl ND, Wissing TE (1987) Nutritional importance of detritivory in the growth and condition of gizzard shad in an Ohio reservoir. Environ Biol Fish 2:129-142

Newton AA (1994) Ranching versus farming in Stegastes nigricans Lacapede (Pisces: Pomacentridae), a territorial herbivore. Hons thesis, James Cook University, Townsville

Odum WE (1970) Utilisation of the direct grazing and plant detritus food chains by the striped mullet Mugil cephalus. In: Steele JH (ed) Marine food chains. Oliver \& Boyd, Edinburgh, p 222-240

Paul VJ, Nelson SCi, Sanger HR (1990) Feeding preferences of adult and juvenile rabbitfish Siganus argenteus in relation to chemical defenses of tropical seaweeds. Mar Ecol Prog Ser 60:23-34

Polunin NVC (1988) Efficient uptake of algal production by a single resident herbivorous fish on the reef. J Exp Mar Biol Ecol 123:61-76

Polunin NVC, Klumpp DW (1989) Ecological correlates of foraging periodicity in herbivorous reef fishes of the Coral Sea. J Exp Mar Biol Ecol 126:1-20

Purcell SW, Bellwood DR (1993) A functional analysis of food procurement in two surgeonfish species, Acanthurus nigrofuscus and Ctenochatius striatius (Acanthuridae). Environ Biol Fish 37:139-159

Randall JE, Allen GR, Steene RC (1990) Fishes of the Great Barrer Reef and Coral Sea. Crawford House, Bathurst.

Robertson DR (1984) Cohabitation of competing territorial damselfishes on a Caribboan coral rocf. Ecology $65: 11211135$

This article was presented by $R$. N. Hughes (Senior Editorial Advisor), Bangor, United Kingdom
Robertson DR, Sweatman HPA, Fletcher EA, Cleland MG (1976) Schooling as a mechanism of circumventing the territonality of competitors. Ecology 57:1208-1220

Russ GR (1987) Is rate of removal of algae by grazers reduced inside territories of tropical damselfishes? J Exp Mar Biol Ecol 110:1-17

Russ GR, St John J (1989) Diets, growth rates and secondary production of herbivorous coral reef fishes. Proc 6th tnt Coral Reef Symp 2:37-43

Russell-Hunter WD (1970) Aquatic productivity. Macmillan, New York

Sinsabaugh RL, Linkins AR (1990) Enzymic and chemical analysis of particulate organic matter from a boreal river. Freshwat Biol 23:301-309

Taborsky M, Limberger D (1980) The activity rhythm of Blennius sanguinolentus Pallas, an adaptation to its food source? Mar Ecol 1:143-153

Vanderploeg HA, Scavia D (1979) Two electivity indices for feeding with special references to zooplankton grazing. J Fish Res Board Can 36:362-365

Zar JH (1984) Biostatistical analysis, 2nd edn. Prentice Hall Englewood Cliffs, NJ

Zeller DC (1938) Short terni effects of territurianity of a tropical damselfish and experimental exclusion of large fishes on invertebrates in algal turfs. Mar Ecol Prog Ser 44:85-93

Zoufal R, Taborsky M (1991) Fish foraging periodicıty correlates with dally changes in diet quality. Mar Biol 108: $103-136$

Manuscript first received: September 20, 1996

Revised version accepted: January 27, 1997 